\title{
Perilaku Hidup Bersih dan Sehat (PHBS) Anak Jalanan di Tambun Selatan Kota Bekasi
}

\author{
Atia Mansoorah, ${ }^{1}$ Buti Azfiani, ${ }^{2}$ Titik Respati, ${ }^{3}$ Lisa Adhia,,${ }^{4}$ Herry Garna ${ }^{5}$ \\ ${ }^{1}$ Program Studi Sarjana Fakultas Kedokteran, Universitas Islam Bandung \\ 2,4,5 Bagian Ilmu Kesehatan Anak, Fakultas Kedokteran Universitas Islam Bandung \\ ${ }^{3}$ Bagian Ilmu Kesehatan Masyarakat, Fakultas Kedokteran Universitas Islam Bandung
}

\begin{abstract}
Abstrak
Anak jalanan masih menjadi masalah di Indonesia khususnya Kecamatan Tambun Selatan, Kota Bekasi yang mewakili daerah kumuh dan tingkat kriminal yang tinggi. Lingkungan memengaruhi perilaku anak jalanan yang identik dengan kelalaian perilaku hidup bersih dan sehat (PHBS) sehingga penelitian ini dilakukan untuk mengetahui hubungan karakteristik anak jalanan dengan PHBS di Kecamatan Tambun Selatan, Kota Bekasi. Penelitian dilakukan dari Januari-Juli 2018. Instrumen berupa kuesioner dan wawancara tentang karakteristik, mencuci tangan, sikat gigi, buang air besar di toilet, dan merokok pada anak jalanan usia 7-18 tahun, tidak hidup nomaden, dapat membaca dan menulis, serta dapat mengikuti pendidikan dari awal hingga akhir. Metode penelitian merupakan cross sectional dengan desain penelitian analitik kategorik tidak berpasangan, uji chi square, Fisher's Exact, Goodman dan Kruskal Tau, dan Kendall's Tau-b. Mayoritas dari 80 orang adalah 44 perempuan, 57 orang berusia 7-12 tahun, dan 47 orang berpendidikan sekolah dasar (SD). Terdapat hubungan yang signifikan antara karakteristik jenis kelamin dan PHBS (nilai $\mathrm{p}=0,04$ ). Selain itu, terdapat hubungan yang signifikan antara karakteristik status pendidikan dan PHBS (nilai $\mathrm{p}=0$,049). Kesimpulannya, mayoritas anak jalanan di Kecamatan Tambun Selatan tergolong tidak ber-PHBS, namun perempuan lebih ber-PHBS dibanding dengan laki-laki dan status pendidikan SD lebih ber-PHBS dibanding status pendidikan lain.
\end{abstract}

Kata kunci: Anak jalanan, karakteristik, PHBS

\section{Clean and Healthy Life Behavior (PHBS) of Street Children in Tambun Selatan Bekasi City}

\begin{abstract}
Street children are still a problem in Indonesia especially Tambun Selatan Sub-district, Bekasi City that represent slum area and high criminal rate. The environment influences the behavior of street children that is identical with the neglect of clean and healthy life behavior so that this research was done to know the characteristic relationship with the clean and healthy life behavior of street children in Tambun Selatan Sub-district, Bekasi City conducted from January to July 2018. The instrument was conducted by giving questionnaires and interviews about the characteristics of street children, hand washing, toothbrush, defecate in the toilet, and smoking to street children aged 7-18 years, not living nomadic, can read and writing, and willing to take part from the beginning to the end. This study was a cross sectional research with unpaired categorical analytic analytic research design, using Chi Square, Fisher's Exact, Goodman and Kruskal Tau, and Kendall's Tau-b statistical test. The majority from 8o people were 44 girls, 57 people aged 7-12 years, and 47 people elementary school educated. There was a significant relationship between sex and clean and healthy life behavior $(\mathrm{p}=0.04)$. In addition, there was a significant relationship between the status of education and clean and healthy life behavior $(\mathrm{p}=0.049)$. In conclusions, the majority of street children in Tambun Selatan Sub-district are classified as not good in clean and healthy life behavior but girl is better than boy and elementary school education status is better than other education status.
\end{abstract}

Keywords: Characteristics, clean and healthy life behavior, street children

Korespondensi: Atia Mansoorah, Fakultas Kedokteran Universitas Islam Bandung, Taman Sari, Bandung, Jawa Barat. Mobile: o85222393038 E-mail: atiamansoorah@gmail.com 


\section{Pendahuluan}

Anak jalanan masih menjadi masalah di berbagai negara terutama negara berkembang seperti Indonesia. Menurut perkiraan United Nations Children's Fund (UNICEF) masih terdapat sekitar puluhan juta anak jalanan di dunia. ${ }^{1}$ Provinsi Jawa Barat, Indonesia termasuk jajaran terbesar dengan jumlah sekitar 11.452. ${ }^{2}$ Jumlah anak jalanan di Kota Bekasi yang terdata pada tahun 2013 sekitar 207 orang. ${ }^{3}$ Kecamatan Tambun Selatan, Kota Bekasi merupakan daerah yang kumuh dan tindak kriminalitas tinggi memungkinkan lingkungan yang tepat untuk seseorang menjadi anak jalanan. ${ }^{4}$

Seorang anak menjadi anak jalanan umumnya disebabkan oleh lingkungan sosioekonomi berupa kemiskinan, perceraian, perpisahan kedua orangtua, kematian orangtua, penyalahgunaan alkohol dan psikotropika, serta putus sekolah. ${ }^{5}$ Hal tersebut berpengaruh pada perilaku hidup bersih dan sehat (PHBS) anak jalanan yang terabaikan. ${ }^{6}$ Berdasar atas penelitian Respati dan Sufrie $^{7}$ dikatakan faktor lingkungan merupakan salah satu yang kompleks sebagai penentu perilaku sehat seseorang.

Perilakuhidupbersih dan sehat merupakanberagam perilaku yang bisa meningkatkan kemandirian dalam kesehatan dan mewujudkan kesehatan di masyarakat yang dapat diterapkan dalam kehidupan sehari-hari sebagai kebiasaan agar dapat menerapkan cara-cara hidup sehat dalam rangka menjaga, memelihara, dan meningkatkan kesehatan. ${ }^{8}$ Kesehatan dan perilaku sehat seseorang ditentukan oleh pengaruh di berbagai tingkat, termasuk salah satunya adalah lingkungan, yaitu sosial dan fisik. ${ }^{6}$ Keterkaitan lingkungan yang kurang baik masuk di dalamnya pengetahuan yang kurang baik pada anak jalanan menyebabkan PHBS mereka pun kurang baik. ${ }^{9}$

Penelitian pendahuluan telah menunjukkan bahwa karakteristik anak jalanan berkaitan dengan PHBS berdasar tempat tinggal, atas lama hidup di jalanan, hubungan dengan keluarga, dan pendidikan yang dapat dirangkum menjadi karakteristik berupa lingkungan baik secara fisik, sosial, maupun ekonomi yang berhubungan pula dengan masalah kesehatan mereka. ${ }^{10}$ Hal yang menyangkut anak jalanan ini pun merupakan masalah pediatrik sosial yang harus ditelusuri sehingga penelitian ini bertujuan menilai hubungan karakteristik anak jalanan dengan perilaku hidup bersih dan sehat (PHBS) pada anak jalanan di Kecamatan Tambun Selatan, Kota Bekasi.

\section{Metode}

Penelitian ini dilakukan terhadap anak jalanan berusia 7 sampai 18 tahun di Kecamatan Tambun Selatan, Kota Bekasi yang berjumlah 80 orang dimulai dari bulan Januari sampai Juli tahun 2018. Sampel memenuhi kriteria inklusi berupa anak jalanan yang berusia 7 sampai 18 tahun, tidak hidup nomaden, dapat membaca dan menulis, serta bersedia mengikuti kegiatan dari awal hingga selesai. Selain itu, tidak memenuhi kriteria eksklusi berupa anak jalanan yang mengalami cacat mental dan dalam pengaruh lem atau psikotropika. Sampel penelitian ini dipilih dengan teknik purposive sampling menggunakan rumus besar sampel analitik komparatif kategorikal tidak berpasangan. Penelitian merupakan analitik cross sectional dengan desain penelitian analitik komparatif kategorikal tidak berpasangan yang diambil mempergunakan formulir dan wawancara yang menanyakan karaktersitik termasuk usia, jenis kelamin, status pendidikan, PHBS berupa mencuci tangan dengan air mengalir dan sabun, sikat gigi, $\mathrm{BAB}$ di jamban, serta merokok. Penelitian menggunakan uji statistika chi square, Fisher's Exact, Goodman and Kruskal Tau, Kendall's Tau-b untuk menilai hubungan karakteristik anak jalanan dan perilaku hidup bersih dan sehat pada anak jalanan. Penelitian ini layak untuk dilaksanakan dan telah diuji oleh Komite Etik Fakultas Kedokteran Universitas Islam Bandung melalui surat Nomor: 235/Komite Etik.FK/III/2018.

\section{Hasil}

Karakteristik anak jalanan

Tabel 1 Karakteristik Demografi Anak Jalanan

\begin{tabular}{|c|c|c|}
\hline Variabel & Kategori & $\mathbf{n}=\mathbf{8 0}$ \\
\hline \multirow[t]{2}{*}{ Usia (tahun) } & $7-12$ & 57 \\
\hline & $13-18$ & 23 \\
\hline \multirow[t]{2}{*}{ Jenis kelamin } & Laki-laki & 36 \\
\hline & Perempuan & 44 \\
\hline \multirow[t]{4}{*}{ Status pendidikan } & Tidak sekolah & 22 \\
\hline & SD & 47 \\
\hline & SMP & 8 \\
\hline & SMA & 3 \\
\hline \multirow[t]{3}{*}{ Pekerjaan di jalanan } & Jualan & 6 \\
\hline & Pengamen & 55 \\
\hline & Pekerjaan lain & 19 \\
\hline \multirow[t]{2}{*}{ Lama menjadi anak jalanan } & $\geq 1$ th & 68 \\
\hline & $<1$ th & 12 \\
\hline \multirow[t]{5}{*}{ Pekerjaan ayah } & Jualan & 6 \\
\hline & Karyawan pabrik & 2 \\
\hline & Pemulung & 38 \\
\hline & Pengamen & 14 \\
\hline & Pekerjaan lain & 16 \\
\hline \multirow[t]{3}{*}{ Pekerjaan ibu } & Ibu rumah tangga & 29 \\
\hline & Pemulung & 20 \\
\hline & Pekerjaan lain & 17 \\
\hline \multirow[t]{2}{*}{$\begin{array}{l}\text { Penghasilan rerata } \\
\text { (Rupiah/bulan) }\end{array}$} & $100.000-500.000$ & 71 \\
\hline & $600.000-1000.000$ & 9 \\
\hline
\end{tabular}


Tabel 2 Karakteristik Gejala Penyakit yang Pernah Dialami Anak Jalanan

\begin{tabular}{lcc}
\hline \multicolumn{1}{c}{ Variabel } & Kategori & $\mathbf{n = 8 0}$ \\
\hline Gejala gatal & Tidak & 6 \\
\multirow{3}{*}{ Gejala ISPA } & Ya & 74 \\
& Tidak & 12 \\
Diare & Ya & 68 \\
& Tidak & 5 \\
& Ya & 75 \\
\hline
\end{tabular}

Tabel 1 menunjukkan anak jalanan di Kecamatan Tambun Selatan umumnya lebih dari setahun menjadi anak jalanan dengan rerata lebih dari 4 jam di jalan. Mayoritas perempuan, usia 7-12 tahun dengan status pendidikan umumnya SD serta pekerjaan umumnya adalah pengamen. Mayoritas pekerjaan ayah anak jalanan merupakan pemulung dan ibu merupakan ibu rumah tangga. Penghasilan orangtua tidak menentu sering kali sekitar 100.000-500.000 rupiah dalam sebulan. Tabel 2 menunjukkan gejala penyakit yang paling umum terjadi adalah diare.

Tabel 3 Hubungan PHBS dengan Karakteristik Anak Jalanan Berupa Jenis Kelamin, Usia, dan Status Pendidikan

\begin{tabular}{|c|c|c|c|c|}
\hline \multirow{3}{*}{ Karakteristik } & \multicolumn{3}{|c|}{ PHBS } & \multirow{3}{*}{$\begin{array}{c}\text { Nilai } \\
\mathbf{p}\end{array}$} \\
\hline & $\begin{array}{c}\text { Ber- } \\
\text { PHBS }\end{array}$ & $\begin{array}{c}\text { Tidak ber- } \\
\text { PHBS }\end{array}$ & Total & \\
\hline & $n=34$ & $n=46$ & $\mathbf{n}=\mathbf{8 0}$ & \\
\hline Jenis kelamin & & & & 0,004 \\
\hline Laki-laki & 9 & 27 & 36 & \\
\hline Perempuan & 25 & 19 & 44 & \\
\hline Usia (tahun) & & & & 0,540 \\
\hline $7-12$ & 23 & 34 & 57 & \\
\hline $13-18$ & 11 & 12 & 23 & \\
\hline Status pendidikan & & & & 0,049 \\
\hline Tidak sekolah & 7 & 15 & 22 & \\
\hline $\mathrm{SD}$ & 19 & 28 & 47 & \\
\hline SMP & 7 & 1 & 8 & \\
\hline SMA & 1 & 2 & 3 & \\
\hline
\end{tabular}

Tabel 3 menunjukkan anakjalanan mayoritas tidak ber-PHBS. Jenis kelamin berhubungan bermakna dengan PHBS, yaitu perempuan memiliki PHBS yang lebih baik dibanding dengan laki-laki. Status pendidikan pun berhubungan bermakna dengan PHBS anak jalanan, yaitu pada status pendidikan sekolah dasar lebih banyak yang ber-PHBS. Walaupun usia tidak berhubungan bermakna dengan PHBS mencuci tangan dan menyikat gigi, namun usia berhubungan bermakna dengan BAB di jamban dan merokok.

\section{Pembahasan}

Dari hasil penelitian ini anak jalanan Kecamatan Tambun Selatan, Kota Bekasi yang tepatnya berada pada lapak Kalibiru umumnya sudah lebih dari setahun menjadi anak jalanan rerata lebih dari 4 jam di jalan. Mayoritas berjenis kelamin perempuan usia 7-12 tahun dengan status pendidikan SD. Berdasar atas hasil wawancara mayoritas anak jalanan tersebut memiliki alasan menjadi anak jalanan karena mengikuti teman. Hubungan baik antaranak jalanan membuat mereka senang turun ke jalan. Umumnya pekerjaan mereka merupakan pengamen. Mereka terbiasa mendapat penghasilan sekitar 20.000 rupiah per hari yang mereka gunakan untuk membeli kuota internet. Beberapa anak yang sudah remaja menggunakan uang tersebut untuk membeli rokok. Kedua orangtua masih hidup dan menyetujui mereka sebagai anak jalanan. Pekerjaan ayah mayoritas merupakan pemulung dan ibu merupakan ibu rumah tangga. Penghasilan orangtua tidak menentu antara 100.000 sampai 500.000 ribu rupiah per bulan.

Anak jalanan tersebut masih banyak yang tidak berPHBS, yaitu sekitar 46 orang dari 80 orang. Lingkungan yang tergolong dari sosioekonomi yang rendah menentukan PHBS anak jalanan tersebut. ${ }^{9}$ Namun, dari jumlah tersebut laki-laki lebih banyak yang tidak ber-PHBS dan sebaliknya perempuan lebih ber-PHBS. Berdasar atas hasil wawancara hal tersebut disebabkan oleh kebiasaan perempuan yang lebih memperhatikan kebersihan diri dibanding dengan laki-laki. Hal ini sejalan dengan penelitian pendahuluan berupa metaanalisis pada tahun 1981, 2000, dan 2010 dengan hasil menunjukkan perempuan lebih menjaga kebersihan dan lebih sering menyikat gigi dibanding dengan lakilaki yang dilakukan oleh mahasiswa kedokteran gigi Greek, Yunani, yaitu Mamai Homata dkk. ${ }^{11}$

Walaupun usia anak jalanan tidak berhubungan bermakna dengan PHBS berupa mencuci tangan dan menyikat gigi, namun usia berhubungan bermakna dengan PHBS berupa BAB di jamban dan merokok. Berdasar atas hasil wawancara pada usia anak sekolah dini, yaitu 7-12 tahun memiliki kecenderungan anggapan bahwa merokok belum diperbolehkan pada usia sekolah dini, namun diperbolehkan saat remaja atau dewasa sehingga ketidakseimbangan jumlah sampel penelitian yang banyak merupakan anak usia sekolah dini dibanding dengan usia sekolah remaja memengaruhi hasil. Selain itu, terdapat tradisi malu untuk anak usia remaja sehingga mereka mengupayakan BAB di jamban, walaupun tidak memiliki jamban sendiri.

Usia berkaitan dengan status pendidikan bahwa usia sekolah dini yang banyak menyandang status pendidikan SD lebih ber-PHBS dibanding dengan usia sekolah remaja yang lebih banyak menyandang status pendidikan tidak sekolah. Oleh karena itu, kecenderungan untuk tidak mendapat pengetahuan dan pengalaman mengenai PHBS lebih mungkin terjadi pada anak jalanan usia sekolah remaja yang lebih banyak tidak sekolah. Hal tersebut sejalan dengan penelitian pendahuluan yang dilakukan di Kelurahan Merjosari, Kecamatan Lowokwaru, Kota Malang pada bulan Mei sampai Juni 2012 dengan hasil terdapat hubungan antara pengetahuan usia sekolah 
dan PHBS anak jalanan oleh Buramare dkk. ${ }^{9}$

Pengetahuan yang didapat menentukan perilaku hidup bersih dan sehat dan pengetahuan tersebut umumnya didapat dari pendidikan. Sesuai data yang didapat bahwa status pendidikan berpengaruh terhadap perilaku hidup bersih dan sehat anak jalanan. Hal tersebut sejalan dengan penelitian pendahuluan yang dilakukan di penampungan anak jalanan di UPTD Kampoeng Anak Negeri Liponsos Kota Surabaya oleh Husna dan Reliani. ${ }^{12}$

Keterbatasan penelitian ini berupa instrumen yang dipergunakan terbatas dan bukan merupakan standar instrumen PHBS anak jalanan, responden lebih banyak berusia 7-12 tahun yang kurang paham dalam menjawab pertanyaan mengenai karakter diri dan PHBS, keadaan sosioekonomi yang sama sehingga cenderung memiliki fasilitas hidup yang sama, terutama jamban yang belum tersedia sehingga memiliki kebiasaan PHBS yang cenderung hampir sama antarkategori yang dibandingkan.

\section{Simpulan}

Berdasar atas data yang diperoleh dari penelitian di Kecamatan Tambun Selatan, Kota Bekasi dapat disimpulkan terdapat hubungan karakteristik dengan PHBS pada anak jalanan di Kecamatan Tambun Selatan, Kota Bekasi. Sebagian besar responden perempuan, usia 7-12 tahun, status pendidikan SD, dan tidak ber-PHBS. Penelitian dapat dilanjutkan untuk penelitian selanjutnya.

\section{Ucapan Terima kasih}

Penulis mengucapkan terima kasih kepada seluruh anak jalanan di Kecamatan Tambun Selatan yang terlibat sebagai sampel penelitian, Ahmad Khair selaku ketua anak jalanan, dan bapak Otik selaku pihak berwenang di Lapak kalibiru.

\section{Daftar Pustaka}

1. Cumber SN, Tsoka-Gwegweni JM. Characteristics of street children in Cameroon: a cross-sectional study. Afr J Prim Heal Care Fam Med. 2016 Nov 28;8(1):1-9.

2. Herlina A. Kehidupan anak jalanan di Indonesia: faktor penyebab, tatanan hidup dan kerentanan berperilaku menyimpang. Aspirasi. 2014 Des 22;5(1):145-56.

3. Badan Pusat Statistik Kabupaten Bekasi. Kabupaten Bekasi dalam angka. Bekasi: Badan Pusat Statistik Kabupaten Bekasi; 2015.

4. Dinkes Kota Bekasi. Profil kesehatan Kota Bekasi tahun 2014. Bekasi: Dinas Kesehatan Kota Bekasi; 2014.

5. Embleton L, Lee H, Gunn J, Ayuku D, Braitstein P. Causes of child and youth homelessness in developed and developing countries. JAMA Pediatr. 2017 Jul 05;170(5):435-44.

6. Galloway DA, Laimins LA, Division B, Hutchinson F. Social determinants and health behaviors: conceptual frames and empirical advances. HHS Pub. 2016 Oct 01;5:87-92.

7. Respati T, Sufri A. Faktor sosial budaya dalam pengobatan tuberkulosis paru: kasus Pare-Pare Kota Sulawesi Selatan. GMHC. 2014;2:1-6.

8. Kementerian Kesehatan Republik Indonesia. Panduan pembinaan dan penilaian perilaku hidup bersih dan sehat di rumah tangga. Jakarta: Kementerian Kesehatan Republik Indonesia; 2011.

9. Buramare M, Yudiernawati A, Nurmaningsih T. Pengetahuan anak anak jalanan (usia sekolah) berhubungan dengan pelaksanaan perilaku hidup bersih dan sehat (PHBS). Nurs News. 2017;2(2):71-9.

10. Cumber SN, Tsoka-Gwegweni JM. Health profile of street children in Africa: a literature riview. J Pub Heal Afr. 2015;6:566-75.

11. Mamai-Homata E, Koletsi-Kounari H, Margaritis V. Gender differences in oral health status and behavior of Greek dental students: a meta-analysis of 1981, 2000, and 2010 data. J Int Soc Prev Com Dent. 2016;6(1):60-8.

12. Husna AR, Reliani. Peningkatan hygiene personal pada anak jalanan dengan media komik di UPTD kampung anak negeri liponsos kecamatan Medoan Ayu Rungkut Surabaya. Indones J Heal Sci. 2016 Jun;6(2):160-9. 


\title{
Hubungan Pola Minum dengan Perubahan Indeks Massa Tubuh pada Mahasiswa Tingkat Satu Fakultas Kedokteran Unisba
}

\author{
Silma Nur Awali Wardah, ${ }^{1}$ Fajar A. Yulianto, ${ }^{2}$ Wiwiek Setiowulan ${ }^{3}$ \\ ${ }^{1}$ Program Pendidikan Sarjana Kedokteran, Fakultas Kedokteran Universitas Islam Bandung \\ ${ }^{2}$ Bagian Ilmu Kesehatan Masyarakat, Fakutas Kedokteran Universitas Islam Bandung \\ ${ }^{3}$ Bagian Pediatrik Fakultas Kedokteran Universitas Islam Bandung
}

\begin{abstract}
Abstrak
Indeks massa tubuh (IMT) adalah ukuran untuk menunjukkan status gizi pada orang dewasa. Kuliah yang sangat padat menjadi salah satu alasan untuk melewatkan minum dan dapat memengaruhi status gizi yang berujung overwight dan underwight sehingga menyebabkan peningkatan risiko penyakit tidak menular. Tujuan penelitian mengetahui hubungan pola minum dengan perubahan IMT pada mahasiswa tingkat satu Fakultas Kedokteran Uiversitas Islam Bandung. Jenis penelitian adalah analitik observasional dengan desain kohort prospektif pada 73 responden yang dilakukan pada bulan April hingga Juni 2019. Data pola minum diambil dengan metode food recall 24 jam setiap 3 kali dalam seminggu selama 2 bulan dan IMT diambil dengan pengukuran berat badan dan tinggi badan sebanyak 3 kali dalam 2 bulan. Data dianalisis menggunakan uji chi square. Hasil penelitian menunjukkan sebagian besar mahasiswa tingkat satu konsumsi air hariannya masih di bawah rekomendasi jumlah air minum, yaitu sebanyak 55 orang (63\%) konsumsi harian kurang dari 1 liter/hari. Nilai tengah konsumsi minuman berpemanis adalah $348 \mathrm{~mL} /$ hari di atas konsumsi dunia. Uji chi square menunjukkan tidak terdapat hubungan yang bermakna pola minum dengan perubahan IMT $(\mathrm{p}=0,85)$. Simpulan, tidak terdapat hubungan pola minum dengan perubahan IMT.
\end{abstract}

Kata kunci: Indeks massa tubuh, mahasiswa kedokteran, pola minum

\section{Relationship Drinking Patterns and Changes in the Body Mass Index to Students Level One Faculty of Medicine Unisba}

\begin{abstract}
Body mass index (BMI) is a measure to indicate nutritional status in adults. A very hectic lecture class is one reason to skip drinking and can affect nutritional status which results in overweight and underweight, which causes an increased risk of non-communicable diseases. The purpose of this study was to determine the relationship between drinking patterns and changes in BMI among first-year students at the Faculty of Medicine, Unisba. This type of research was an observational analytic with a prospective cohort design on 73 respondents conducted in April to June 2019. Drinking habit data was taken by food recall method 24 hours every 3 times a week for 2 months and BMI is taken by measuring body weight and height as much as 3 times in 2 months. Data were analyzed using chi square test. The results showed that most of the first year students had their daily water consumption still below the recommended amount of drinking water, which was 55 people (63\%) daily consumption of less than 1 liter per day. The median consumption of sweetened drinks was $348 \mathrm{~mL} /$ day above world consumption. Chi square test showed no significant relationship between drinking habit with changes in BMI $(\mathrm{p}=0.85)$. In conclusion, there is no relationship drinking pattern and changes in BMI.
\end{abstract}

Keywords: Body mass index, medical students, drinking habit 


\section{Pendahuluan}

Berdasar atas World Health Organization (WHO) di seluruh dunia sekitar 2,8 juta orang meninggal setiap tahun akibat overweight dan obesitas. ${ }^{1}$ Pada tahun 2016, lebih dari 1,9 miliar orang dewasa usia 18 tahun ke atas mengalami kelebihan berat badan dan pada jumlah tersebut lebih dari 650 juta mengalami obesitas. ${ }^{2}$ Prevalensi obesitas di dunia antara tahun 1980 dan 2008 mengalami peningkatan hampir dua kali lipat, yaitu $5 \%$ laki-laki dan $8 \%$ perempuan pada tahun 1980 dan menjadi 10\% laki-laki dan $14 \%$ perempuan pada tahun 2008. Peningkatan indeks massa tubuh (IMT) akan memengaruhi peningkatan risiko komplikasi kardiovaskular termasuk hipertensi, dislipidemia, dan diabetes melitus di masa depan. ${ }^{5}$

Adapun beberapa faktor yang dapat memengaruhi IMT, yaitu (1) usia, prevalensi obesitas meningkat secara terus menerus dari usia 20-60 tahun karena kerja metabolisme tubuh semakin menurun; (2) jenis kelamin, pria lebih banyak mengalami overweight dibanding dengan wanita; (3) genetik, beberapa studi membuktikan bahwa faktor genetik dapat memengaruhi berat badan seseorang. Penelitian menunjukkan bahwa orangtua obesitas menghasilkan proporsi tertinggi anak-anak obesitas; (4) aktivitas fisik yang kurang; dan (5) pola makan yang tidak teratur. ${ }^{2}$ Untuk mengatasi hal tersebut maka meningkatkan konsumsi air putih telah lama dianggap sebagai salah satu strategi untuk menurunkan berat badan. ${ }^{3}$ Mengonsumsi air putih yang baik dan cukup bagi tubuh dapat membantu proses pencernaan, mengatur metabolisme, mengatur zat-zat makanan dalam tubuh, dan mengatur keseimbangan tubuh. ${ }^{4}$ Dilaporkan oleh Daniels dan Popkin ${ }^{4}$ bahwa studi potong lintang yang dilakukan National Health and Nutrition Examination Survey (NHANES) di Amerika Serikat menunjukkan bahwa konsumsi air putih yang lebih banyak berhubungan dengan asupan energi yang lebih sedikit.

Penelitian mengenai efek konsumsi air putih pada orang dewasa kebanyakan dilakukan pada subjek yang tengah dalam program menurunkan/ mempertahankan berat badan, bukan pada populasi umum. Seperti diketahui, mereka yang sedang dalam program diet cenderung secara sadar mengurangi porsi makan dan meningkatkan aktivitas fisiknya. Dengan demikian, belum diketahui apakah konsumsi air putih juga bermanfaat dalam menurunkan berat badan pada populasi umum orang dewasa yang tetap mempertahankan pola makan dan aktivitasnya seperti biasa.

Di lain pihak, konsumsi minuman berpemanis terbukti berhubungan dengan kenaikan berat badan dan obesitas..$^{5,6}$ Peneliti melihat bahwa kecenderungan saat ini semakin banyak remaja dan dewasa muda yang mengonsumsi minuman berpemanis karena telah menjadi tren dan kegemaran di kalangan generasi milenial. Gerai penjual minuman manis ini dijual dalam porsi besar dengan harga hemat dibanding dengan porsi yang lebih kecil dan saat ini tersedia di mana-mana, mulai di pinggir jalan hingga pusat perbelanjaan. ${ }^{6}$ Mempertimbangkan hal tersebut di atas, penulis tertarik meneliti mengenai hubungan antara pola minum dan perubahan IMT pada mahasiswa tingkat satu Fakultas Kedokteran Universitas Islam Bandung.

\section{Metode}

Penelitian ini dilakukan menggunakan metode analitik observasional dengan desain kohort prospektif pada 73 responden yang dilakukan pada bulan April hingga Juni 2019 pada mahasiswa tingkat satu Fakultas Kedokteran Universitas Islam Bandung. Data pola minum diambil dengan metode food recall 24 jam setiap 3 kali dalam seminggu selama 2 bulan dan IMT diambil dengan pengukuran berat badan dan tinggi badan sebanyak 3 kali dalam 2 bulan. Data dianalisis menggunakan Uji Eksak Fisher. Data kemudian diolah dan dianalisis menggunakan uji chi-square. Penelitian ini telah mendapat persetujuan etik dari Komite Etik Penelitian Kesehatan Fakultas Kedokteran Universitas Islam Bandung Nomor: 142/Komite Etik FK/IV/2019.

\section{Hasil}

Responden penelitian ini adalah mahasiswa angkatan 2018 Fakultas Kedokteran Universitas Islam Bandung yang berjumlah 88 orang yang ditentukan secara simple random sampling, tetapi dari 88 orang yang ikut hanya 87 orang yang minum air putih dan 1 orang tidak minum air putih. Tahap selanjutnya dilakukan pengisian google form food recall setiap 3 hari selama 24 jam setiap minggunya dalam kurun waktu 2 bulan dan pengukuran berat badan dan tinggi badan sebanyak 3 kali dalam 2 bulan untuk menghitung indeks massa tubuh (IMT).

Tabel 1 Proporsi Jumlah dan Proporsi Jenis Air Minum Harian

\begin{tabular}{lcc}
\hline & $\begin{array}{c}\text { Jumlah } \\
\text { Sampel (n) }\end{array}$ & $\begin{array}{c}\text { Persentase } \\
\text { (\%) }\end{array}$ \\
\hline $\begin{array}{l}\text { Jumlah air minum/hari } \\
\text { 1-2 }\end{array}$ & 32 & 37 \\
$<1$ & 55 & 63 \\
Jenis air minum & 14 & 16 \\
$\quad$ Air putih & 1 & 1 \\
$\quad \begin{array}{l}\text { Air berpemanis } \\
\text { Air putih dan } \\
\text { berpemanis }\end{array}$ & 73 & 82 \\
\hline
\end{tabular}

Tabel 1 menunjukkan bahwa dari 87 orang yang menjadi subjek penelitian ini, $63 \%$ memiliki konsumsi harian kurang dari 1 liter per hari di bawah rekomendasi jumlah air minum harian. Kebanyakan (82\%) minum air putih berpemanis dan sering tidak minum air putih (1\%). 

Tabel 2 Hubungan Pola Minum dengan

\begin{tabular}{|c|c|c|c|c|c|c|}
\hline \multirow{3}{*}{ Pola Minum } & \multicolumn{4}{|c|}{ Indek Massa Tubuh } & \multirow{3}{*}{$\begin{array}{l}\text { Total } \\
\mathbf{n}=\mathbf{8 8}\end{array}$} & \multirow{3}{*}{$\begin{array}{c}\text { Nilai } \\
\quad \text { p }\end{array}$} \\
\hline & \multicolumn{2}{|c|}{ Tetap/turun } & \multicolumn{2}{|c|}{ Naik } & & \\
\hline & $n=49$ & $\%$ & $\mathbf{n}=\mathbf{3 9}$ & $\%$ & & \\
\hline $\begin{array}{l}\text { Minum } \\
\text { berpemanis } \\
<30 \%\end{array}$ & 26 & 53 & 23 & 47 & 49 & \\
\hline $\begin{array}{l}\text { Minum } \\
\text { berpemanis } \\
\geq 30 \%\end{array}$ & 23 & 59 & 16 & 41 & 39 & 0,58 \\
\hline
\end{tabular}

Tabel di atas menunjukkan bahwa 49 dari 88 orang minum minuman berpemanis kurang dari $30 \%$, IMT naik (antara IMT 1 dan 3 ) terjadi di $44 \%$ responden. $\mathrm{P}$ chi square 0,58 sehingga disimpulkan tidak terdapat hubungan yang signifikan antara pola minum berpemanis dan perubahan IMT. Subjek yang memberikan keterangan jumlah air minum hanya 87 orang, lebih sedikit daripada yang mengisi data pola minum (88 orang). Tidak terdapat hubungan yang signifikan antara jumlah air minum/hari dan IMT (P o,77).

Tabel 3 Hubungan antara Pola Minum dan Perubahan IMT

\begin{tabular}{ccccc}
\hline $\begin{array}{c}\text { Perubahan } \\
\text { IMT }\end{array}$ & Koefisien & P (z) & P (chi) & $\begin{array}{c}\text { Pseudo } \\
\text { R sq }\end{array}$ \\
\hline Pola minum & $-0,24$ & 0,58 & & \\
Kalori & $-0,0001$ & 0,93 & 0,85 & 0,003 \\
Konstanta & $-0,07$ & 0,93 & & \\
\hline
\end{tabular}

Tabel 2 menunjukkan perbedaan nilai tengah jumlah air minum berpemanis dan nilai tengah jumlah kalori antara kedua kelompok tersebut. Korelasi antara variabel utama dan variabel kontrol didapat dalam korelasi antara air berpemanis, air putih, dan kaloriair putih. Korelasi bersifat positif karena peningkatan jumlah salah satu variabel akan disertai peningkatan variabel lain. Hal yang menarik adalah tidak terdapat korelasi linear yang signifikan antara air manis dan kalori.

\section{Pembahasan}

Pada penelitian ini ditemukan fakta empiris bahwa mahasiswa Kedokteran tingkat satu Universitas Islam Bandung cenderung memiliki proporsi jumlah air minum harian yang kurang daripada standar asupan air minum per hari, yaitu sebanyak 1 sampai 2,5 liter atau setara dengan 6-8 gelas setiap harinya. ${ }^{4}$ Proporsi jumlah air minum mahasiswa Kedokteran tingkat satu Universitas Islam Bandung tersebut tentu merupakan perilaku yang negatif dan dapat berdampak kepada kesehatan seperti dijelaskan pada penelitian Drewnowski yang menyatakan bahwa asupan air kurang dari yang direkomendasikan dapat menjadi berbagai penyebab masalah kesehatan seperti dehidrasi yang mengakibatkan efek pada kinerja mental, fungsi kognitif, performa fisik, penurunan konsentrasi, mudah lelah, dan sakit kepala.?

Hasil penelitian di atas menguatkan pernyataan Ivan Tack dalam konferensi pers Indonesian Hydration and Health Conference di Fakultas Kedokteran Universitas Indonesia (FKUI) yang menjelaskan saat kekurangan cairan, tubuh akan mengeluarkan hormon vasopresin yang meningkatkan hormon stres kortisol pemicu inflamasi kronis dalam waktu lama. Akibatnya, dalam jangka panjang, tubuh dapat memproduksi batu ginjal, mengalami gagal ginjal, hingga infeksi kandung kemih. Selain itu, kekurangan cairan juga dapat jadi pemicu awal mula penyakit kronis seperti diabetes melitus, kardiovaskular, dan sindrom metabolik. ${ }^{8}$

Lebih jauh lagi, nilai tengah konsumsi air berpemanis pada responden lebih tinggi daripada rerata konsumsi dunia. Nilai median konsumsi minuman berpemanis pada responden adalah 348 $\mathrm{mL} /$ hari, sedangkan rerata konsumsi dunia adalah $135 \mathrm{~mL} /$ hari. Konsumsi minuman berpemanis yang berlebih berhubungan dengan peningkatan risiko DM tipe 2 dan obesitas. ${ }^{9}$

Guna memastikan hubungan antara pola minum dan perubahan IMT maka dilakukan uji chi square yang hasilnya ternyata pola minum tidak memiliki hubungan dengan perubahan IMT, begitu juga dengan jumlah air minum yang dikonsumsi tidak memiliki hubungan dengan perubahan IMT. Hasil penelitian ini berlawanan dengan penelitian Stookey dkk. terdapat penurunan berat badan yang lebih besar (2,3 kg) dan lingkar pinggang $(2,3 \mathrm{~cm})$ pada responden yang minum lebih dari 1 liter per hari dengan waktu lebih dari 12 bulan.

Selain itu, proporsi minuman berpemanis juga tidak berhubungan dengan perubahan IMT. Temuan ini tidak sesuai dengan penelitian Malik dkk. ${ }^{5}$ bahwa asupan minuman berpemanis terbukti berhubungan dengan obesitas dan dapat meningkatkan risiko diabetes militus tipe 2 dan penyakit kardiovaskular.

Mayoritas mahasiswa Fakultas Kedokteran adalah perempuan dan biasanya ingin menjaga postur tubuh tetap ideal sehingga memilih minuman berpemanis dan mengurangi porsi makan. Akibatnya, asupan gizinya menjadi tidak seimbang dan dapat berisiko mengalami kekurangan mikronutrien, seperti defisiensi zat besi, kalsium, dan lain-lain.

Kemungkinan lain tidak terdapat hubungan antara pola minum dan perubahan IMT pada mahasiswa Kedokteran tingkat satu Universitas Islam Bandung kemungkinan diakibatkan oleh sumbangan energi dari air berpemanis dapat menekan nafsu makan. Berdasar atas teori glucostatic bahwa peningkatan karbohidrat sederhana yang berasal dari minuman berpemanis terbukti dapat memengaruhi penurunan nafsu makan karena kadar glukosa tinggi dalam darah sehingga individu tidak akan meningkatkan asupan energinya melebihi kebutuhan.

Gula yang terkandung dalam 300-500 mL satuan saji minuman berpemanis yang beredar di Indonesia adalah sekitar 37-54 gram, melebihi 4 kali rekomendasi penambahan gula yang aman pada minuman, yaitu 6-12 gram. Selain itu, faktor aktivitas fisik mahasiswa Kedokteran tingkat satu Universitas Islam Bandung yang berbeda tidak diperhitungkan (dikontrol) dalam 
penelitian ini yang mungkin berperan pada hasil analisis yang tidak bermakna.

\section{Simpulan}

Berdasar atas penelitian pada mahasiswa Kedokteran tingkat satu Universitas Islam Bandung dapat disimpulkan bahwa jumlah konsumsi harian air minum sebagian besar mahasiswa mengonsumsi air putih, namun masih di bawah rekomendasi jumlah air minum harian. Pola minum tidak memiliki hubungan dengan perubahan IMT.

\section{Ucapan Terima kasih}

Ucapan banyak terima kasih kami tujukan kepada pengurus Badan Eksekutif Mahasiswa (BEM) Fakultas Kedokteran Universitas Islam Bandung serta semua pihak yang telah membantu pelaksanaan penelitian ini.

\section{Daftar Pustaka}

1. WHO | Mean Body Mass Index (BMI). WHO [Internet]. 2017 [diunduh 3 Jan 2019]. Tersedia dari: $\quad$ https://www.who.int/gho/ncd/risk_ factors/bmi_text/en/

2. Asil E, Surucuoglu MS, Cakiroglu FP, Ucar A, Ozcelik AO, Yilmaz MV, dkk. Factors that affect body mass index of adults. Pakistan J Nutr [Internet]. 2014 May 1 [diunduh 8 Jan 2019]; 13(5):255-60. Tersedia dari: http://www.scialert. net/abstract/?doi=pjn.2014.255.260.

3. Tri P, Purnama SI. Tingkat pengetahuan tentang pentingnya mengkonsumsi air $\mathrm{m}$ ineral pada siswa kelas IV di SD Negeri Keputran A Yogyakarta [Internet]. Vol. 10, Pendidikan Jasmani Indones 2014; [diunduh 9 Jan 2019]. Tersedia dari: https://journal.uny.ac.id/index.php/jpji/article/ viewFile/5701/4926

4. Daniels MC, Popkin BM. Impact of water intake on energy intake and weight status: a systematic review. Nutr Rev [Internet]. 2010 Sep [diunduh 8 Feb 2019];68(9):505-21. Tersedia dari: http:// www.ncbi.nlm.nih.gov/pubmed/20796216

5. Malik VS, Popkin BM, Bray GA, Després JP, Hu FB. Sugar-sweetened beverages, obesity, type 2 diabetes mellitus, and cardiovascular disease risk. Circulation. 2010;121(11):1356-64.

6. Pakpahan PK. Hubungan kebiasaan minum air putih dan faktor lainnya dengan asupan air total pada siswa-siswi SMP Negeri 1 Depok tahun 2014. [diunduh 13 Feb 2019]. Tersedia dari: http://lib. ui.ac.id/abstrakpdf.jsp?id=20386200

7. cnnindonesia.com. Kurang minum air mineral berujung penyakit kronis [Internet]. Https:// Www.Cnnindonesia.Com/. 2018. Tersedia dari: https://www.cnnindonesia.com/gayahidup/20181108115037-255-344924/kurangminum-air-mineral-berujung-penyakit-kronis

8. Singh GM, Micha R, Khatibzadeh S, Shi P, Lim S, Andrews KG, dkk. Global, regional, and national consumption of sugar-sweetened beverages, fruit juices, and milk: a systematic assessment of beverage intake in 187 countries. PLoS One. 2015;10(8):1-20.

9. Akhriani M, Fadhilah E, Kurniasari FN. Hubungan konsumsi minuman berpemanis dengan kejadian kegemukan pada remaja di SMP Negeri 1 Bandung. Indones J Hum Nutr. 2015;1(1):57-70. 